\title{
Clusters as Ecosystems: Exploring the Diversity in Mimar Kemalettin Fashion District in Izmir
}

\section{Onur Mengi*}

\begin{abstract}
Today, many industry structures are found in the form of clusters, implicating the existence of certain spatial and non-spatial proximities amongst firms, and these clusters can also be described and approached as ecosystems. Recently, Mimar Kemalettin Fashion District has become a focus of various design-related initiatives in Izmir, particularly in the process of constructing a Design City role for future. A major initiative is to promote the district as a wedding wear capital, both spatially and organizationally. In that, there is a need for comprehensive research to explore and evaluate the particular structure of the emerging wedding wear cluster on the site. The aim of the present study is to investigate how the ecosystem of this clustering in the Mimar Kemalettin Fashion District in Izmir operates in terms of diversity, especially for determining future planning decisions. The methodology of the study consists of the following: literature review on the diversity in the fashion industry, taking the wedding wear as its sub-set, data collection via site visits, and the diversity measure questionnaire conducted on site, as well as data processing through descriptive analyses and evaluations. The findings point out that the existing wedding wear sector cluster is still young and emerging, and currently self-operates in a compact spatial structure with limited diversity.
\end{abstract}

Keywords: Clusters, wedding wear, ecosystem, diversity, Mimar Kemalettin Fashion District

\section{Özet \\ Ekosistem Olarak Kümeler: Mimar Kemalettin Moda Merkezi'nde Çeşitliliği Araştırmak}

Günümüzde çoğu endüstri yapısı, firmaların birbirlerine mekânsal ve mekânsal olmayan yakınlıkları ile ortaya çıkan ve ekosistem olarak tarif edilen kümeler halinde bulunmaktadırlar. Son dönemlerde, özellikle gelecekteki Tasarım Kenti rolünün kurgulanması sürecinde, Mimar Kemalettin Moda Merkezi'nin, İzmir'deki tasarım temelli birçok girişiminin odağında olduğu görülmektedir. Bu girişimlerin en önemlilerinden biri de bu bölgenin mekânsal ve organizasyonel olarak gelinlik başkenti olarak gelişmesini içermektedir. Bu anlamda, bu bölgede oluşmakta olan gelinlik kümesinin kendine has yapısının araştırılması ve değerlendirilmesine yönelik geniş kapsamlı bir araştırmaya ihtiyaç duyulmaktadır. Bu mevcut çalışmanın amacı, Izmir'deki Mimar Kemalettin Moda Merkezi'nde kümelenen gelinlik sektörü ekosisteminin, özellikle alınacak planlama kararları için, çeşitlilik bakımından nasıl işlediğinin araştırılmasıdır. Çalışma, gelinlik sektörünü moda endüstrisinin bir alt sektörü olarak ele almaktadır. Moda endüstrisi içerisindeki çeşitliliğe odaklanan çalışmanın yöntemi mevcut literatürün gözden geçirilmesi, alan ziyaretleri ile genel alan verilerinin toplanması ve özellikle çeşitlilik ölçümlerine ilişkin anket çalışmalarının yürütülmesi, betimleyici değerlendirmeler ile verilerin analizi süreçlerini kapsamaktadır. Bu araştırmanın sonuçları, mevcut gelinlik sektör kümesinin genç ve oluşmakta olan bir küme olduğunu ve halihazırda çeşitliliğin kısıtlı olduğu kompakt bir yapıda kendi kendine işlediğini göstermektedir.

Anahtar sözcükler: Kümeler, gelinlik sektörü, ekosistem, çeşitlilik, Mimar Kemalettin Moda Merkezi

\footnotetext{
* Izmir University of Economics, Department of Industrial Design
} 


\section{Introduction}

There has been a growing interest in the spatiality of industries among Turkish scholars over the last decade. However, most studies conducted and scholarly events have concentrated on the case of Istanbul. ${ }^{1}$ In terms of its central position in commercial and economical activities and its global reputation, Istanbul can be described as the center of Turkish fashion, home to most creative activities and institutions of education, and various related fairs, activities and fashion shows parallel. Izmir appears as a secondary center, with its growing design education opportunities, and the recent attempts to transform into a Design City through developing art and design based activities and services. There is a therefore need for a comprehensive research to explore and evaluate the spatial and organizational structure of the emerging wedding wear cluster as sub-sector of fashion industry in Izmir, both due to its current major role as a sectoral driver of Turkey, and its place in the global trade market. Izmir dominates the Turkish wedding wear sector. The conditions for this sector have been studied in recent research reports of the Izmir Development Agency (IZKA). ${ }^{2}$ However, these studies are rather conventional, restricted to economic sphere of analysis, leaving organizational structure and particular locational distribution of the sector cluster unexplored.

The role of fashion in identity-formation resulted in fashion becoming a serious aspect in city planning. Throughout the past years, the city of Izmir fell behind in the global inter-urban competition and began to lose its appeal among the other Mediterranean cities. Consequently, the Metropolitan Municipality, in collaboration with the representatives from different sectors, non-government organizations, and universities, has made efforts to re-gain its previous status by envisioning a creativity-based development. Drawing a new path for Izmir's future development is currently regarded as an urgency by the local government. Moreover, in terms of its creative potential, fashion industry is found at the core of such intentions. Especially with the recent developments, Izmir Metropolitan Municipality has started to prioritize the fashion industry as a creative sector -and in particular, on the wedding wear sector as a subsector, due to increasing profits and opportunities. The wedding wear sector and its ecosystem have therefore become vital for creativity-based development in Izmir.

The object of this study is to explore the existing ecosystem of wedding wear sector in Izmir. As a case study, it focuses on Mimar Kemalettin Fashion District. This choice is based on the assumption of a significant role for the so-called ecosystem of the wedding wear sector in Mimar Kemalettin Fashion District, of which existing manufacturers are not only the founders, but the

1 Bahar Durmaz, Stephen Platt and Tan Yigitcanlar, "Creativity, Culture Tourism and Placemaking: Istanbul and London Film Industries," International Journal of Culture, Tourism and Hospitality Research 4, no. 3 (2010): 198-213; Evinc Dogan, "City as Spectacle: The Festivization of Culture in Contemporary Istanbul" in Young Minds Rethinking the Mediterranean, ed. Mensur Akgün and Lenka Petkova (Istanbul: Istanbul Kültür Üniversitesi Publication, 2011): 69-93; Zeynep Merey Enlil, Yigit Evren, and Iclal Dincer, "Cultural Triangle and Beyond: A Spatial Analysis of Cultural Industries in Istanbul," Planning, Practice E Research 26, no. 2 (2011): 167-183.

2 See the details in IZKA, İzmir Kümelenme Stratejisinin Geliştirilmesi Projesi İzmir ve İlçeleri İstatistiki Analiz Raporu (İzmir: İzmir Kalkınma Ajans1, 2009), accessed February 6, 2014. http://www.izka.org.tr/files/kumelenme_istatistik_analiz_raporu.pdf; IZKA， Izmir Kümelenme Analizi İzmir ve İlçeleri İstatistiki Analiz Raporu (İzmir: İzmir Kalkınma Ajansı, 2010), accessed March 6, 2014. http://www.investinizmir.com/upload/Node/27782/ xfiles/Izmir_Kumelenme_Analizi.pdf; IZKA, İzmir Mevcut Durum Analizi (İzmir: İzmir Kalkınma Ajansı, 2013), accessed March 6, 2014. http://www.izmiriplanliyorum.org/ static/upload/file/mda_39.pdf. 
primary, structural, functional, and biological units of this ecosystem. The ecosystem approach is used as a metaphor to describe the operation of the clusters in this Fashion District. ${ }^{3}$

The field research of this study led to the recording of 266 wedding wear firms, including manufacturers of wedding dresses, wedding suits and evening gowns, and 31 suppliers of buttons, yarns, fabrics, laces, beads associated with the sector. Wedding wear firms across Mimar Kemalettin Fashion District were asked to participate in a survey. The questionnaires were conducted from February 2 to March 12, 2015. The respondents were firm owners and managers. In cases where the owner or manager could not be reached on the site, or for those whose workplace was other than the firm premises, the questionnaires were delivered by the firms' own employees. Thus, all the questionnaires have been filled with owners or managers of the firms.

Among the 266 wedding wear firms, 28 were engaged only in wedding wear retailing, and therefore, were excluded from the questionnaire. In order to reach all the manufacturing firms, site visit requests up to a maximum of seven were made to those firms that initially declined to participate. Eventually, 132 manufacturers, approximately $55 \%$ of the total population, responded to question, participated to the questionnaire.

The paper first gives an overview of the research approach which conceptualizes clusters as ecosystems, and looks at the diversity in ecosystems in order to understand the structure of the emerging wedding wear cluster as sub-sector of fashion industry. After presenting the role of Izmir wedding wear sector, the study explores the diversity dynamics in fashion industry ecosystems, and builds a series of inquiries for the diversity measure questionnaire prepared for the site. In the section that follows, findings are reconsidered from the wedding wear sectoral perspective. The case study investigates the cluster of wedding wear sector in Mimar Kemalettin Fashion District in Izmir, and presents findings derived from the analyses. Following, the analyses are evaluated in terms of diversity in this ecosystem.

\section{The Ecosystem Approach}

The ecosystem approach as a research perspective of this study is utilized as a tool that is able to explain operation of creative industries in certain environments. ${ }^{4}$ One complex aspect that characterizes the spatiality of industries is the presence of particular systems that regulate and inform the environment. This conceptualization provides a more in-depth approach, allowing the investigation of the unique formations of business ecosystems, particularly through

3 See the metaphoric use of the term in Nancy Duxbury and Murray Catherine, "Creative Spaces," in Cultural Expression, Creativity and Innovation, ed. Helmut K. Anheier, Yudhishthir Raj Isar, and Christopher Alan Waterman (Los Angeles: SAGE, 2010); Greg Hearn, Simon Roodhouse, and Julie Blakey, "From Value Chain to Value Creating Ecology: Implications for Creative Industries Development Policy," International Journal of Cultural Policy 13 (2007): 419-436; Jim Shorthose, "Nottingham's De Facto Cultural Quarter: The Lace Market, Independents and a Convivial Ecology," in City Of Quarters: Urban Villages In The Contemporary City, ed. David Bell and Mark Jayne (London: Routledge, 2004), 149-162; Ron Dvir and Pasher Edna, "Innovation Engines for Knowledge Cities: An Innovation Ecology Perspective," Journal of Knowledge Management 8 (2004): 16-27; Deng-Neng Chen, Ting-Peng Liang, and Binshan Lin, "An Ecological Model for Organizational Knowledge Management," Journal of Computer Information Systems 50 (2010): 11-22.

4 Edward Maltby, "Ecosystem Approach: From Principle to Practice," paper presented at the Ecosystem Service and Sustainable Watershed Management in North China International Conference, Beijing, P.R. China, 2000; Jean-Yves Pirot, Meynell Peter-John and Elder Danny, eds., Ecosystem Management: Lessons from around the World: A Guide for Developmenta and Conservation Practitioners (Gland, Switzerland and Cambridge, UK: IUCN, 2000). 
exploring the diversity characteristics of wedding wear sector in Izmir.

\section{Clusters as Ecosystems}

The term "cluster" is derived from Michael Porter's works on industrial/business clusters, ${ }^{5}$ in which a wide range of interactions, diversity of complementary skills, and evolving knowledge allow particular places to achieve a competitive advantage. Porter defines cluster as a geographically proximate group of inter-connected companies and associated institutions in a particular field, linked by commonalities and complementarities, while also stating that the geographic scope of a cluster can range from a single city or state to a country or even a group of neighboring countries. ${ }^{6}$ The economic factors that contribute to such concentration entail cost-savings in the production chain and joint venture. When firms are highly inter-dependent in certain geographies, a creation is co-produced by the entire ecosystem. The ecosystem approach recognizes that humans are an integral component of ecosystem. Clusters as ecosystems are open systems containing dynamic interactions between individual firms, and their surrounding environment, as well as other ecosystems. Therefore, the ecosystem emerges around the diversified members and interactions. Diversity appears as one of the major characteristics of such ecosystems, and is central to the ecosystems of industry clusters.

\section{Diversity in Clusters}

Diversity is a crucial factor in understanding why clusters exist and how they can enhance the knowledge-creation process. At the firm level, groups whose members have more diverse configurations outperform the more homogeneous groups. In this respect, it is appropriate to divide the concept of diversity into two: The primary dimensions are the unchangeable variables that are inborn as age, gender, ethnicity, physical features, race and sexual orientation. There have considerable influence on our development in early socialization as well as for our lives. The secondary dimensions are the changeable variables, such as education, geographic location, income, marital status and religious beliefs. Both dimensions are very relevant and significant to ecosystems. Diversity should not be viewed as consisting of only racial or religious differentiation, but is the combination as well as distribution of all differences. Diversity means the variations among employees from all these sources, including variations with respect to the other ecosystems of which they are a part. Thus, diversity within firms, among individuals, and between ecosystems should all be taken into consideration. The role of diversity in fostering inspiration stems from not only the mix of people in that particular environment, but also diversity in the physical environment. The built environment provides an extra facilitation of the chances of accidental or deliberate encounters, and of new combinations, resulting in rising productivity, just as the diversified urban areas show faster growth ratio rates compared to cities that are rather homogeneous in economic, social and spatial terms.?

Physical variety and human diversity are vital to the business ecosystems. Fashion as a system aims at, on the one hand, preserving the diversity, and on the other, enabling progress and change, and imposing a unified meaning and linking

5 See the use of terms in Michael E. Porter, "Locations, Clusters, and Company Strategy," in The Oxford Handbook of Economic Geography, ed. Gordon L. Clark, Maryann P. Feldman, Meric S. Gertler (Oxford, New York: Oxford University Press, 2000), 253-274; Michael E. Porter, "Location, Competition, and Economic Development: Local Clusters in a Global Economy," Economic Development Quarterly 14 (2000): 15-34.

6 Porter, "Locations, Clusters, and Company Strategy," 254.

7 Barbara Heebels and Irina van Aalst, "Creative Clusters in Berlin: Entrepreneurship and the Quality of Place in Prenzlauer Berg and Kreuzberg," Geografiska Annaler: Series B, Human Geography 92 (2010): 347-363. 
its parts together. Thus, the whole field of fashion is driven by diversity, associated with the ideology of choice and taste developed by the consumer culture. Both the transformations of taste and the ideology of choice are derived from the diversity of experience occurring in fashion-related interactions, thus, diversity appears as a crucial requirement. Many fashion districts attract young artists and designers through their spatial dynamism and diversified use of buildings. ${ }^{8}$

The diversity of individuals in the fashion system, and diversity of their surrounding environment both have a dramatic influence on behavior, and the survival and reproductive success of firms. These two types of diversity influence dynamics and stability at the same time. Diverse experiences, cultural backgrounds, professions, academic backgrounds, ages, and personalities all contribute to the creation of fruitful dialogues based on multiple perspectives. Similar people generate similar ideas therefore, it is important for the fashion industry draws from diversity in different ways. Fashion designers who emphasize the creative side of their work tend to portray creativity as the result of interaction with other workers and the ecosystem, emphasizing the contribution of diverse influences from the inner and outer environments. Here, it is also essential to mention that apart from designers there are other workers, therefore it is not only the range of designers (in numbers or skills) but also the diversity of that production team, with all the components, that enables the system to function, and facilitates creativity. Such teamwork is not only internal to the firm but also external to it. ${ }^{9}$

For the fashion ecosystem, there exists a diverse input from various disciplines, sectors and stakeholder interests. This is a necessity for constructing and evaluating information on the basis of the interactions in the use of goods and the provision of services by the system. Fashion is a diverse and collective process, which links many different people, and firms from different proximities and professions. In the fashion market, there is a wide range of intermediaries directing the fashion industry and creating diversity within the system. These intermediaries range from buyers and stylists, fashion editors, journalists, models, photographers, hairdressers and make-up artists, fashion forecasters, fashion-related educational institutions, fashion fairs and fashion weeks, fashion magazines, and advertising agencies to more recent phenomenon such as new medias as marketing and consumption websites, and social networking websites, fashion bloggers. The fashion market depends on a diverse group who cannot be classified according to certain class or status, but share characteristic of being separate from the mainstream. ${ }^{10}$

The measure of diversity derived from the literature discussions above, along with the particular context, necessary research questions are adapted for the diversity measure questionnaire conducted on the site. The diversity measurements are based on variables in firms that can be changed and unchanged, size and qualifications of firms, distribution of different actors, specific production processes in the value chain of the wedding wear sector in particular.

\section{Wedding Wear Sector in Izmir}

The wedding wear sector, by definition, cover all the processes, from production and distribution to consumption of wedding dresses, wedding suits and evening gowns. There are also suppliers and other related sectors that complement the wedding wear sector, including textiles, accessories, bags and shoes.

8 Doreen Jakob, Beyond Creative Production Networks (Berlin: Rhombos, 2009).

9 Ruwandika Senanayake, "Fashion Design for the Emerging Creative Economy of Sri Lanka," (MA thesis, RMIT University, Melbourne, 2013), accessed December 12, 2015. https://researchbank.rmit.edu.au/eserv/rmit:160577/Senanayake.pdf.

10 Louise Crewe and Jonathan Beaverstock, "Fashioning the City: Cultures of Consumption in Contemporary Urban Spaces," Geoforum 29 (1998): 287-308. 
Turkey has recently been the supplier of the wedding dresses, wedding suits and evening gowns to Europe and the Middle East. The conditions of sector was studied by Izmir Development Agency in 2009, 2010 and 2013 focusing on the sectoral clusters in Izmir, and by a research group from Izmir University of Economics in $2013 .{ }^{11}$ In the findings of the research project conducted by Izmir University of Economics in 2013, the wedding wear sector has been analyzed in terms of its strengths, weaknesses, opportunities and threats. For its strengths, knowledge-intensive character of the sector was underlined. Since the wedding wear manufacturing is a knowledge-intensive process that requires particular know-how and creativity, its final outcome is considerably value-added. ${ }^{12}$ In this respect, the sector requires particularly creative and skillful workers. For the sustainability of the firms and their survival, it is essential to have quality products, trained and/or educated workforce and in-house knowledge. The other strength is the low-level of investment needed to enter to this sector, the cost of first investment, which requires only limited machining and textile and other necessary material supplies, is relatively low. Further, Izmir's geographical location and rooted cultural relations in the Middle Eastearn and North African markets are considered to be one of its essential strengths. Further, wedding wear is accepted as a cultural signifier providing benefits to the sector. As well as, the presence of relatively mature wedding firms, there are contributions from IF Wedding and similar fashion related events as well as an established regional ready-to-wear industry.

In terms of its weaknesses, first of all, insufficient institutionalization is found to be an important shortcoming, as the firms are generally family-based, and form their associations and links through relatives, even at the international level. Also, the lack of brand recognition resulting from brands derived through family names is a weakness, especially for the international competitiveness. Moreover the lack of special sectoral national and regional associations, insufficient promotion and advertisement can be listed as further weaknesses of the sector in Izmir. ${ }^{13}$

Furthermore, opportunities are created by tourism potential, the increasing interest in the Turkish culture in the Middle Eastern region, the growing internationalization awareness as well as the presence of the Free Zone. Finally, the economic instabilities, infrastructure problems and obstacles as well as high rents and property prices are considered as threats. ${ }^{14}$ Yet, despite these weaknesses and risks, for the last decade, Izmir's wedding wear sector has been reported as evolving into a developing cluster.$^{15}$ Research based on statistical data, conducted with the key regional actors in the Izmir Development Agency, has presented three major cluster types for the Izmir metropolitan area: mature, developing and potential clusters (Table 1). ${ }^{16}$

Mimar Kemalettin Fashion District, situated at the city center, Konak, and identified as a potential cluster, has a significant place for the wedding wear production in Izmir. It is a concentrated area where a number of wedding wear firms are situated in close proximity, creating a cluster. Its development and current conditions are explained in detail in the following section as a case study.

11 See the project details in IZKA, Izmir Kümelenme Stratejisi; IZKA, Izmir Kümelenme Analizi; IZKA, İmir Mevcut Durum Analizi.

12 IEU (Izmir University of Economics), Uluslararası Rekabetçiliğin Geliştirilmesi Projesi Gelinlik ve Abiye Sektörü Sektör Raporu (Izmir, 2013), accessed January 7, 2015. http://phoenix.ieu.edu. $\mathrm{tr} /$ betanix/uploads/cms/ekokent.ieu.edu.tr/3979_1394627435.pdf.

13 IEU, Gelinlik ve Abiye Sektörü Sektör Raporu, 26-27.

14 IEU, Gelinlik ve Abiye Sektörü Sektör Raporu, 25.

15 IZKA, İzmir Kümelenme Stratejisi, 37.

16 IZKA, İmir Kümelenme Analizi, 84. 


\section{Case Study: Wedding Wear Cluster in Mimar Kemalettin Fashion District, Izmir}

The case study area covers the wedding wear cluster located around the Mimar Kemalettin Fashion District and adjacent area in Konak, Izmir. The area is situated in the historical downtown between the traditional bazaar area, and the central business district (Figure 1).

In order to understand the diversity regarding the firms on the site, first of all, the size and sectoral experiences of firms are considered, focusing on wedding wear manufacturing firms. As can be seen in Figure 2, the capacity of these firms in terms of the average number of employees is 12 . The ecosystem represented by the respondent firms contains 1675 workers. Except for one relatively large manufacturer with 350 workers, larger companies generally employ between 40-80, engaged in diverse occupations (Figure 2). Firms are distributed homogenously across the site in terms of their sizes, based on the number of their employees (Figure 3).

Regarding the life of the ecosystem, the average firm experience on the site is 11 years. 27 relatively older firms have been in the area for more than 20 years and their experiences change between 20 to 65 years (Figure 4). Older firms in the sector are located along the major axis around Mimar Kemalettin fashion District, particularly along the Mimar Kemalettin Street (Figure 5).

As mentioned in the previous sections, most manufacturers are characterized as producing for their own brands. As can ben seen in Figure 6, 98\% of firms manufacture for their own brands, while a very small proportion operate as outsourcing firms for other brands. More than half of the ecosystem consists of firms with patented brands $(63 \%)$ through certain certifications, and $57 \%$ of the firms' export operations are registered (Figure 6).

The site survey reveals a considerable number of females in terms of the worker profile, with $82 \%$. In addition, less than one third of employees are university graduates. Interestingly, of all workers hired as designers, the proportion of university graduates is only $12 \%$ (Figure 7). A survey of diversity of occupations indicates that there are 16 different job titles (with different proportions) within the firms (Figure 8). Among these, more than two-thirds of the firms hire cutters and mechanists, while craftsmen, ironers, pattern makers, salesmen, accountants and financial personnel and designers.

\section{Evaluation of the Diversity in Mimar Kemalettin Fashion District}

The ecosystem of wedding wear cluster in Mimar Kemalettin Fashion District is mostly represented by wedding wear manufacturers themselves. Manufacturing activities are carried out within this cluster by two-thirds of the firms, while a minority locate their manufacturing processes in other areas, particularly at the MTK Manufacturers Zone in the eastern part of Izmir.

Irrespective of the locational choices of manufacturing, almost all retailing activities of existing firms are currently being conducted within Mimar Kemalettin Fashion District. Almost half of the firms in this ecosystem have no registrations for export or patents for their own brands, yet are still able to maintain the daily export activities through utilizing other companies' sources, or through informal methods. Additional interviews also reveal that many of these manufacturers export manufactured wedding wears especially to the so-called dollar zone in the Middle East. However, half of these export activities are conducted with assistance of firms with their own export registrations. Thus, there are various types of business agreements and cooperation among the firms in this respect.

Based on occupations, the greatest numbers of proportions are employees are in pattern making, cutting, and ironing as well as machinist and craftsmen. However, only half of firms hire designers. Also, it is important to note those described as designer or employee in the survey does not necessarily mean they are certified. "Designer" in the survey responses may describe their function as operational rather 
than implying an educational background in design.

In terms of the two divisions of the concept of diversity within the inner organizations of firms were derived from the theoretical discussions mentioned in the first section, the primary dimensions include constant variables in this respect, the ecosystem contains mainly female workers. For the secondary dimension, i.e. the variables that can be changed, the firms employ university graduates, although very few, less than one third of the existing employees in firms. Especially, for the design background of workers hired as designers, the proportion of university graduate designers is only 10 per cent in this ecosystem.

Furthermore, the product and manufacturing range signifying the consumer culture, and the firm ability for creation variety was explored. There were two main findings. First, half of the firms currently produce for the customers from different socio-economic backgrounds. Second, there is great variation in the taste and ideology of customer choices for manufactured wedding wears. Again, almost half of the firms manufacture wedding wears for customers with diverse tastes and choices. On the other hand, the firms of this ecosystem believe that their current weeding wear designs and collections are not differentiated from the ecosystems operating in other parts of Izmir, i.e. Alsancak and Karsiyaka.

Considering the entire sectoral value chain, the ecosystem contains firms engaged in similar processes; almost all produce for their own brands and conduct their own production process, and engage in only limited number of outsourcing services. However, photo-shooting services including staff and equipment are in great demand and are outsourced by the firms, particularly for catalogs and advertisements. The other services such as design consultancy and trend research outsourced are indeed crucial aspects yet remain very underdeveloped.

\section{Conclusion}

This research concludes that the existing wedding wear sector in Mimar Kemalettin Fashion District is an emerging and self-operating cluster that has a spatially concentrated structure. This structure lacks sufficient diversity in its ecosystem.

Despite the relatively low cost of first investment in Mimar Kemalettin Fashion District, the lifespan of start up businesses is short, unless they are sufficiently knowledgeable and experienced in the sector. Hence, the more experienced and mature the firms, the more resilient they are in this ecosystem. Since the wedding wear production is craftsmanship-led and has a mainly female workforce, the production chain requires a particular composition. There is a distribution of many diverse types of knowledge coming from various professions and job descriptions, particularly from craftsmanship. However, there is still a lack of variety in the creative input and design interventions in wedding wear production in Mimar Kemalettin Fashion District. Also, there is a current lack of intermediaries that lead the industry and create the diversity within the system, and the variety of leisure activities and facilities in the ecosystem. Therefore, the production process is less design-oriented, and the existing ecosystem lacks some important properties of clusters. Moreover, there are few design graduates, it is seen that the designers are involved in the process to a limited extent. This situation reflects in the lack of uniqueness and of diversity in this ecosystem.

Since the wedding wear sector is a sub-set, the ecosystem as a whole can be similarly characterized by a lack of diversity, yet increasingly it is recognized as a means of achieving success. Diversity of the inner organizations of industries and the occupational distributions, and the diversity of the cluster itself-consist- 
ing of different firms, physical variety, human diversity and product variety-is regarded vital to such environments. Nevertheless, it is noted from the vitality perspective that carefully designed socio-economic urban spaces such as sectoral clusters can contribute to integrating creative workers and craftsmanship into everyday culture, and to addressing wider developmental issues and other challenges of the clusters. The planned creative industry clusters is an important driver for broader revitalization initiatives, and plays a role in different economic, social, and cultural aspects of urban development. However, the extent of the possible policies (e.g. urban regeneration projects bringing economic vitality for the district), along with growing interest in the creative industry based development, especially considering the uniqueness of the sector, should be balanced in the future interventions.

\section{Table and Figures}

\begin{tabular}{|l|l|l|l|l|l|l|}
\hline & \multicolumn{2}{|l|}{ Mature Clusters } & \multicolumn{2}{l|}{ Developing Clusters } & \multicolumn{2}{l|}{ Potential Clusters } \\
\hline Sector & $\begin{array}{l}\text { Cooling, } \\
\text { Industrial } \\
\begin{array}{l}\text { Ventilation } \\
\text { and Air } \\
\text { Conditioning }\end{array}\end{array}$ & $\begin{array}{l}\text { Canned } \\
\text { Food }\end{array}$ & $\begin{array}{l}\text { On-Car } \\
\text { Equipment }\end{array}$ & $\begin{array}{l}\text { Chemistry } \\
\text { (used in } \\
\text { ceramic, } \\
\text { leather, glass } \\
\text { sectors) }\end{array}$ & $\begin{array}{l}\text { Wedding } \\
\text { Wear }\end{array}$ & Logistic \\
\hline Place & $\begin{array}{l}\text { Çiğli } \\
\text { Bornova } \\
\text { Konak }\end{array}$ & $\begin{array}{l}\text { Kemalpaşa } \\
\text { Torbalı }\end{array}$ & $\begin{array}{l}\text { Çiğli } \\
\text { Bornova }\end{array}$ & $\begin{array}{l}\text { Konak } \\
\text { Bornova }\end{array}$ & Konak & $\begin{array}{l}\text { Konak } \\
\text { Bornova }\end{array}$ \\
\hline
\end{tabular}

Table 1. Izmir Clustering Categories with Sectors

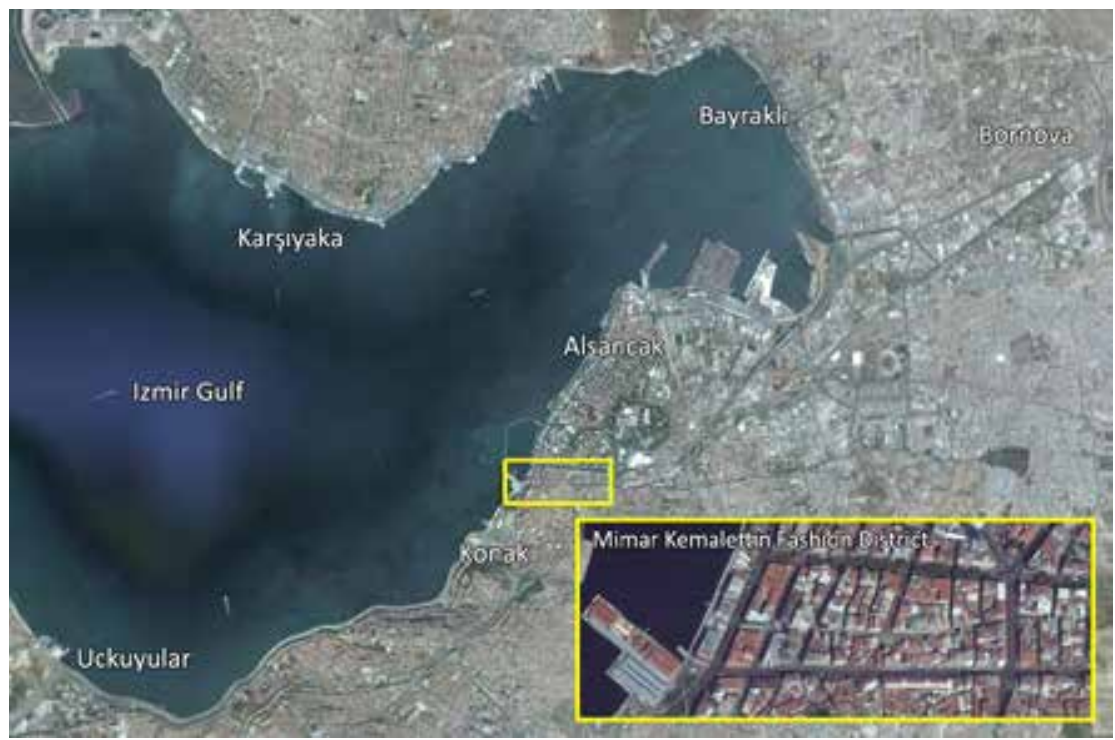

Figure 1. Mimar Kemalettin Fashion District in Izmir: Case Study Area 


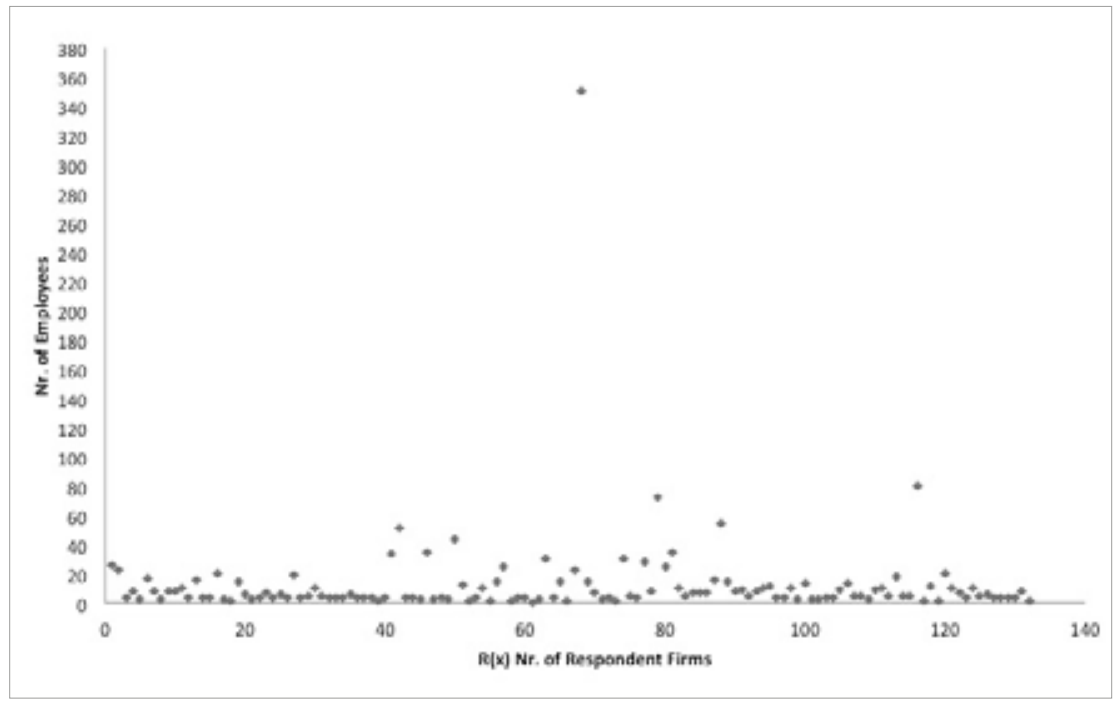

Figure 2. Sizes of Firms

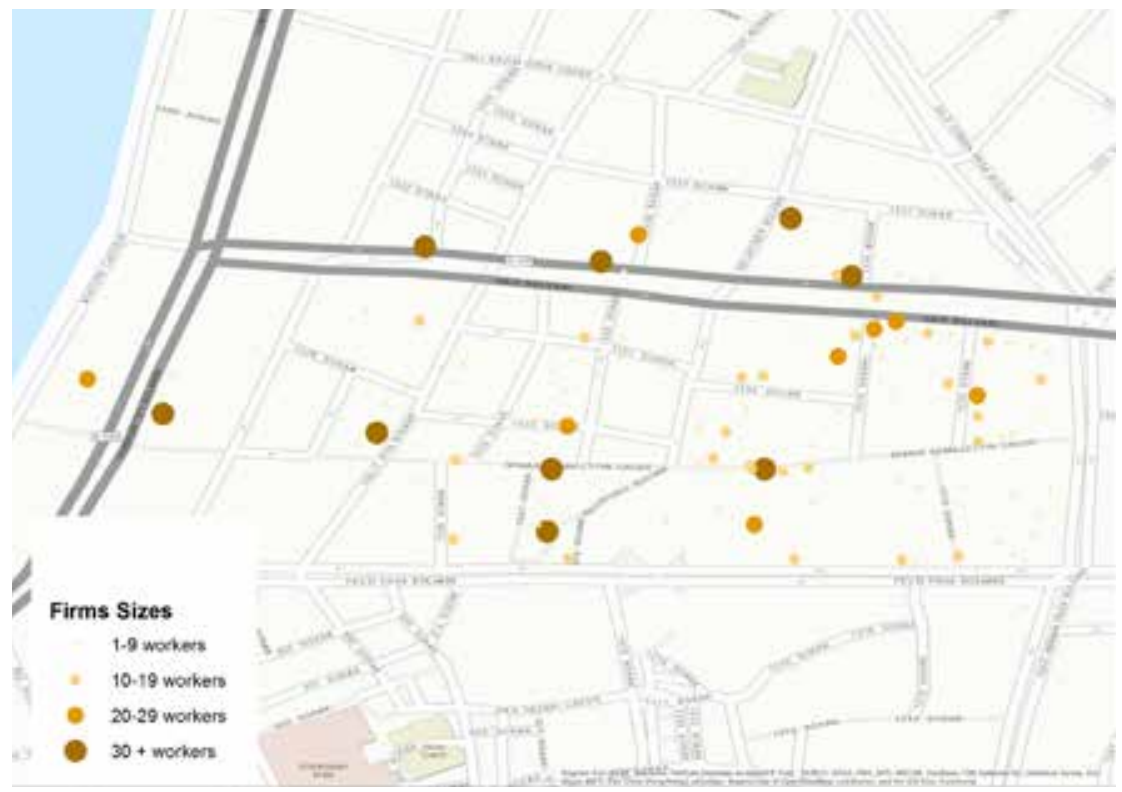

Figure 3. Locational Distribution of Firms' Sizes on Site 


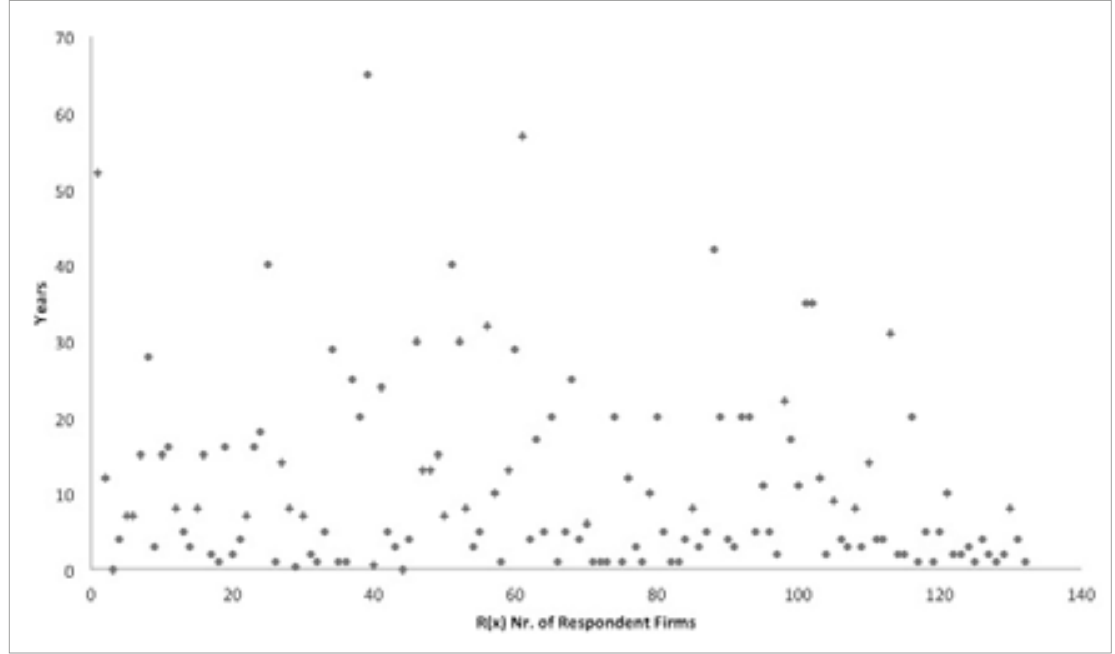

Figure 4. Experience of Firms in the Sector

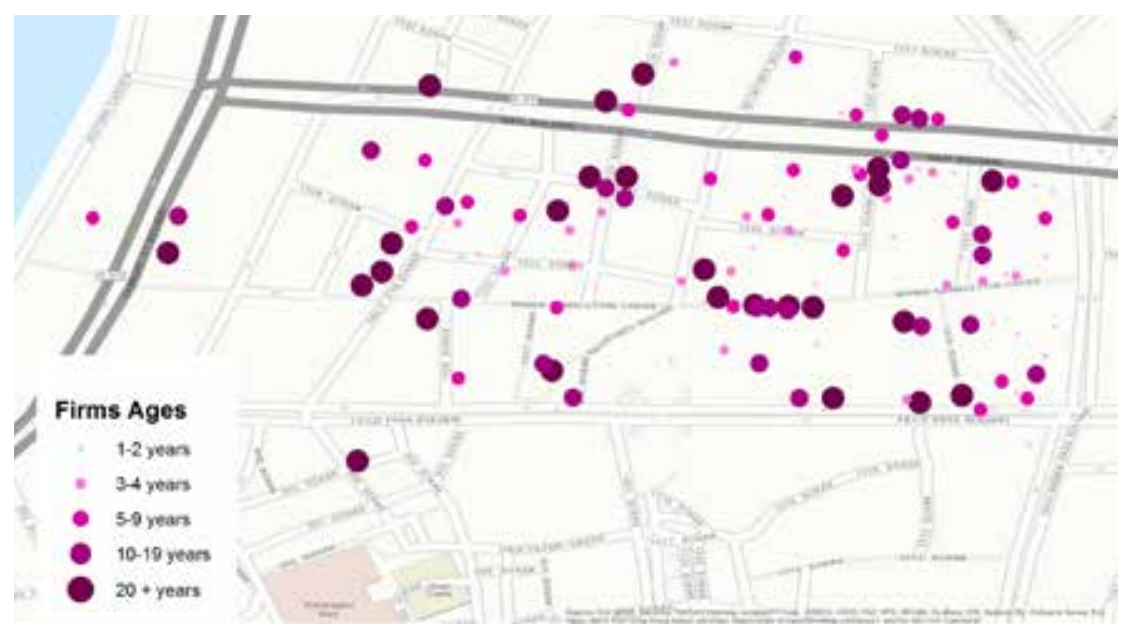

Figure 5. Locational Distribution of Firms' Ages on Site

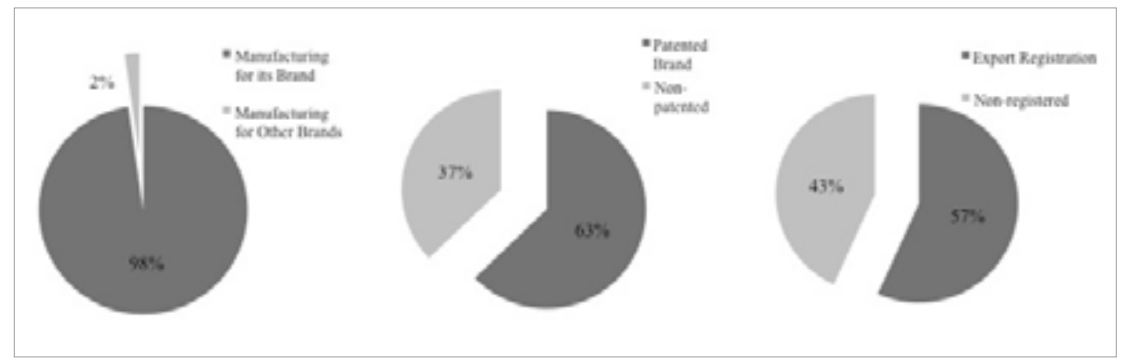

Figure 6. Qualifications of Firms 


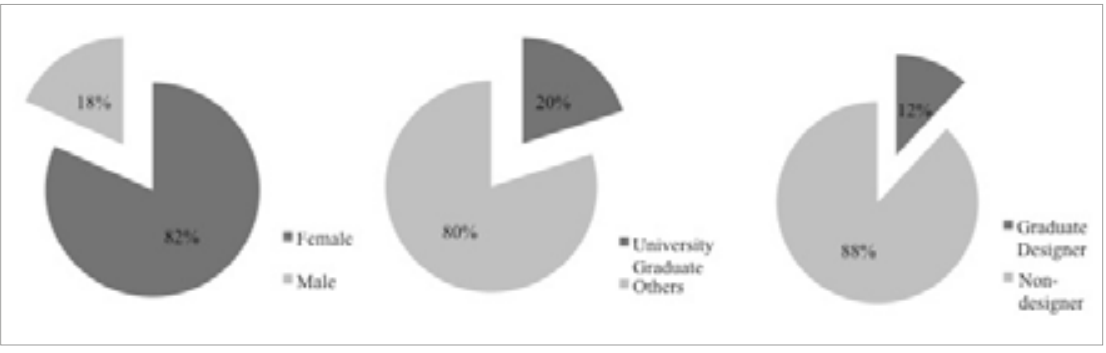

Figure 7. Worker Profile

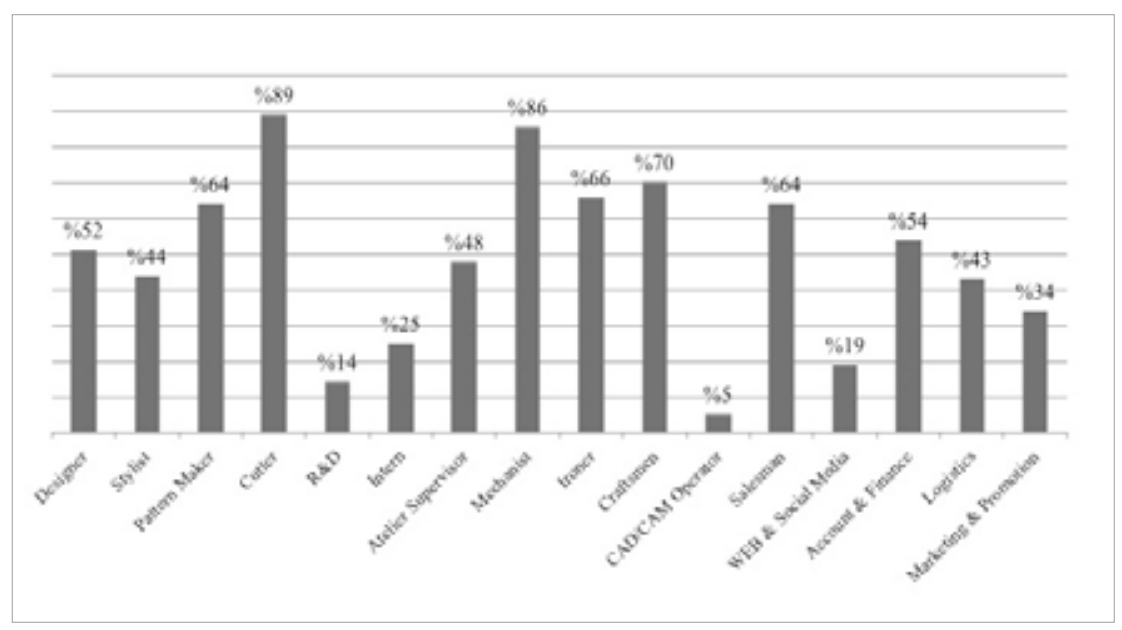

Figure 8. Occupational Distribution in Firms

\section{Bibliography}

Chen, Deng-Neng, Ting-Peng Liang, and Binshan Lin. "An Ecological Model for Organizational Knowledge Management." Journal of Computer Information Systems 50 (2010): 11-22

Crewe, Louise, and Jonathan Beaverstock. "Fashioning the City: Cultures of Consumption in Contemporary Urban Spaces." Geoforum 29 (1998): 287-308.

Dogan, Evinc. "City as Spectacle: The Festivization of Culture in Contemporary Istanbul" In Young Minds Rethinking the Mediterranean, edited by Mensur Akgün and Lenka Petkova, 69-93. Istanbul: Istanbul Kültür Üniversitesi, 2011.

Durmaz, Bahar, Stephen Platt, and Tan Yigitcanlar. "Creativity, Culture Tourism and Place-making: Istanbul and London Film Industries." International Journal of Culture, Tourism and Hospitality Research 4, no. 3 (2010): 198-213.

Duxbury, Nancy and Murray Catherine. "Creative Spaces." In Cultural Expression, Creativity and Innovation, edited by Helmut K. Anheier and Yudhishthir Raj Isar, 20014. Los Angelas: SAGE, 2010.

Dvir, Ron, and Edna Pasher. "Innovation Engines for Knowledge Cities: An Innovation Ecology Perspective.” Journal of Knowledge Management 8 (2004): 16-27.

Enlil, Zeynep Merey, Yigit Evren, and Iclal Dincer. "Cultural Triangle and Beyond: A Spatial Analysis of Cultural Industries in Istanbul." Planning, Practice \& Research 26, no. 2 (2011): 167-183. 
Hearn, Greg, Roodhouse Simon, and Blakey Julie. "From Value Chain to Value Creating Ecology: Implications for Creative Industries Development Policy." International Journal of Cultural Policy 13 (2007): 419-436.

Heebels, Barbara, and Irina van Aalst. "Creative Clusters in Berlin: Entrepreneurship and the Quality of Place in Prenzlauer Berg and Kreuzberg." Geografiska Annaler: Series B, Human Geography 92 (2010): 347-363.

IEU (Izmir University of Economics). Uluslararası Rekabetçiliğin Geliştirilmesi Projesi Gelinlik ve Abiye Sektörü Sektör Raporu, 2013. Accessed January 7, 2015. http://phoenix. ieu.edu.tr/betanix/uploads/cms/ekokent.ieu.edu.tr/3979_1394627435.pdf

IZKA. İzmir Kümelenme Stratejisinin Geliştirilmesi Projesi İzmir ve İlçeleri İstatistiki Analiz Raporu, 2009. Accessed February 6, 2014. http://www.izka.org.tr/files/kumelenme_ istatistik_analiz_raporu.pdf

IZKA. İzmir Kümelenme Analizi İzmir ve İlçeleri İstatistiki Analiz Raporu. İzmir: İzmir Kalkınma Ajansı, 2010. Accessed March 6, 2014. http://www.investinizmir.com/ upload/Node/27782/xfiles/Izmir_Kumelenme_Analizi.pdf

IZKA. İzmir Mevcut Durum Analizi. İzmir: İzmir Kalkınma Ajans1, 2013. Accessed March 6, 2014. http://www.izmiriplanliyorum.org/static/upload/file/mda_39.pdf

Jakob, Doreen. Beyond Creative Production Networks. Berlin: Rhombos, 2009.

Maltby, Edward. “Ecosystem Approach: From Principle to Practice." Paper presented at the Ecosystem Service and Sustainable Watershed Management in North China International Conference, Beijing, P.R. China, 2000.

Pirot, Jean-Yves, Peter-John Meynell, and Danny Elder. Ecosystem Management: Lessons from around the World: A Guide for Development and Conservation Practitioners. Gland, Switzerland and Cambridge, UK: IUCN, 2000.

Porter, Michael E. "Locations, Clusters, and Company Strategy." In The Oxford Handbook of Economic Geography, edited by Gordon L. Clark, Maryann P. Feldman, and Meric S. Gertler, 253-74. New York: Oxford University Press, 2000.

Porter, Michael E. "Location, Competition, and Economic Development: Local Clusters in a Global Economy." Economic Development Quarterly 14 (2000): 15-34.

Senanayake, Ruwandika. Fashion Design for the Emerging Creative Economy of Sri Lanka. MA thesis, RMIT University, 2013. Accessed December 12, 2015. https:// researchbank.rmit.edu.au/eserv/rmit:160577/Senanayake.pdf.

Shorthose, Jim. "Nottingham's De Facto Cultural Quarter: The Lace Market, Independents and a Convivial Ecology." In City of Quarters: Urban Villages in The Contemporary City, edited by David Bell and Mark Jayne, 149-62. London: Routledge, 2004. 